\title{
PREDICTIVE MODELING OF SUITABLE HABITATS FOR THREATENED MARINE INVERTEBRATES AND IMPLICATIONS FOR CONSERVATION ASSESSMENT IN BRAZIL*
}

\author{
Rafael A. Magris ${ }^{1} * *$ and Déstro, G. F. G. ${ }^{2}$ \\ ${ }^{1}$ Instituto Chico Mendes de Conservação da Biodiversidade - ICMBio \\ (EQSW 103/104, Complexo Administrativo, Sudoeste, 70670-350 Brasília, DF, Brasil) \\ ${ }^{2}$ Instituto Brasileiro de Meio Ambiente e dos Recursos Naturais Renováveis - IBAMA \\ (SCEN Trecho 02, Ed. Sede, Asa Norte, Brasília, DF, Brasil) \\ **Corresponding author: rafael.magris@icmbio.gov.br
}

\section{A B S T R A C T}

Spatial analysis and modeling tools were employed to predict suitable habitat distribution for threatened marine invertebrates and estimate the overlap between highly suitable areas for these species and the Brazilian marine protected areas (MPAs). Records of the occurrence of species were obtained from the collections included in the Ocean Biogeographic Information System (OBISBrazil), with additional records culled from the literature. The distribution data of 16 out of 33 threatened species, with at least ten occurrences in the available records, were selected for modeling by Maxent algorithm (Maximum Entropy Modeling) based on environmental variables (temperature, salinity, bathymetry and their derivatives). The resulting maps were filtered with a fixed threshold of 0.5 (to distinguish only the highly suitable areas) and superimposed on MPA digital maps. The algorithm produced reasonable predictions of the species' potential distributions, showing that the patterns predicted by the model are largely consistent with current knowledge of the species. The distribution of the highly suitable areas showed little overlapping with Brazilian MPAs. This study showed how the habitat suitability for threatened species can be assessed using GIS applications and modeling tools.

\section{RESUMO}

Neste estudo foram utilizadas análises espaciais e ferramentas de modelagem para predizer a distribuição dos hábitats adequados aos invertebrados marinhos ameaçados e estimar a sobreposição destas áreas em relação às áreas marinhas protegidas existentes. Registros de ocorrência das espécies foram obtidos das coleções incluídas no Ocean Biogeographic Information System (OBIS-Brasil) e de dados provenientes da literatura. Dados de distribuição de 16 das 33 espécies ameaçadas, com pelo menos 10 registros de ocorrência, foram selecionados para modelagem utilizando o algoritmo Maxent (Maximum Entropy Modeling) e variáveis ambientais (temperatura, salinidade, batimetria e derivados). Os mapas resultantes foram filtrados para obtenção de áreas altamente adequadas, através de um limiar de corte de 0.5 , e sobrepostos com o mapa digital de áreas protegidas. O algoritmo apresentou modelos de predição satisfatórios, mostrando que os padrões previstos no modelo são coerentes com o conhecimento atual sobre as espécies. A distribuição das áreas altamente adequadas mostrou baixa sobreposição com as áreas protegidas brasileiras. Este estudo indicou como a adequabilidade de hábitats para espécies ameaçadas pode ser realizada, utilizando aplicações em SIG e ferramentas de modelagem.

Descriptors: Threatened species, Marine protected areas, Maxent, Conservation. Descritores: Espécies ameaçadas, Áreas marinhas protegidas, Maxent, Conservação.

\section{INTRODUCTION}

The marine system is subject to a large number of anthropogenic threats associated with the development of the coastal zone, discharge of toxic substances, overexploitation of commercially harvested fishes, mariculture, maritime trade and many other activities. As threats to biodiversity increase,

(*) Paper presented at the $2^{\text {nd }}$ Brazilian Congress of Marine Biology, on 24-28 May. Búzios, RJ, Brazil. 2009. conservation managers and donor organizations require increasingly sophisticated tools for decisionmaking; and, above all, ways to prioritize conservation actions that are efficient, accountable and transparent (EDGAR et al., 2008). The conservation of important sites with associated habitats as protected areas is therefore generally seen as the best strategy to maintain biodiversity and ecosystem services (BERTZKY; STOLL-KLEEMANN, 2009; Bruner et al., 2001; MILLENNIUM ECOSYSTEM 
ASSESSMENT, 2005) because they (i.é, the protected areas) protect species from the greatest threat: habitat loss.

At the 2002 Sixth Conference of the Parties to the Convention on Biological Diversity (CBD), a set of 18 indicators were defined for achieving, by 2010 , a significant reduction of the current rate of biodiversity loss at global, regional and national levels (UNEP, 2002). One of these indicators is the percentage of total national land surface legally under protection. The establishment of a $10 \%$ target for protected areas has become deeply entrenched in the thinking of many conservationists and incorporated into the national legislation of many countries for establishing protected areas (LANGHAMMER et al., 2007). A large number of marine protected areas (MPAs) have, therefore, been established around the world, in an attempt to halt further deterioration of sensitive habitats and populations, or to serve as fisheries management tools (PÉREZ-RUZAFA et al., 2008). The spatial extent of MPAs globally has grown at an annual rate of $5.2 \%$ over the last two decades, and approximately 2.2 million $\mathrm{km}^{2}$, equivalent to $0.6 \%$ of the world's oceans, are currently protected (OJEDA-MARTIINEZ et al., 2009).

However, in order to achieve their goals, MPAs should be ecologically representative. According to Harris and Whiteway (2009), to be "representative" the MPA should contain areas that reasonably reflect the biotic diversity of the marine ecosystems from which they derive. In addition, Edgar et al. (2008) highlighted the need to maximize representation and persistence of biodiversity in comprehensive protected areas, focusing especially on threatened and under-protected ecosystems and species threatened with extinction. However, knowledge of Brazilian marine biodiversity is unsatisfactory and uneven, especially for benthic invertebrates (AMARAL; JABLONSKI, 2005). In order to avoid that the lack of data's undermining the integrated management of biodiversity and the implementation of effective policies, techniques of modeling can be used to infer the potential distribution of species and fill the gaps resulting from the lack of biological surveys.

Ecological "niche modeling" using presence-only locality data and large-scale environmental variables provides a powerful tool for identifying and mapping suitable habitats for species over large areas (ROTENBERRY et al., 2006). These models establish relationships between the occurrence of species and biophysical and environmental conditions in the study area. For threatened species, the prediction and mapping of potential suitable habitats are critical for the monitoring and restoration of their declining native populations in their natural habitats, artificial introductions, or selection of conservation sites, and the conservation and management of their native habitats (GASTON, 1996). Furthermore, in terrestrial ecosystems, these tools have been used to estimate the protected ranges for endangered species through the intersection of a species distribution with a digital map of protected areas (ANDERSON; MARTÍNEZ-MEYER, 2004).

The Brazilian red list was published by the Ministry of the Environment in 2004 (MMA, 2008) and contains 83 marine species, being the group of invertebrates which presented the highest number of species (33). The main threats to these organisms are their accidental capture in little selective fishing gear, their capture for ornamental aquaria, overfishing and the destruction of habitats. Furthermore, extensive ecosystems of the Brazilian shelf are subject to from medium to very high impacts in a multiscale spatial model which synthesizes 17 global data sets of anthropogenic drivers of ecological change (HALPERN et al., 2008).

The objective of the current study was to apply techniques of spatial analysis and modeling tools to predict the distribution of suitable habitats for threatened marine invertebrates and, tentatively, to estimate, for conservation purposes, their overlap with the network of Brazilian MPAs.

\section{MATERIAL AND METHODS}

\section{Biological data}

The analysis was performed using 933 distributional records (occurrence points) obtained from the collections included in the Ocean Biogeographic Information System OBIS-Brazil (BROBIS, http://obissa.cria.org.br) as well as data from the literature. OBIS has been reported as a source of marine biodiversity information by several studies with distinct purposes (BEST ET AL., 2007; FABRI et al., 2006; FLEISCHER et al., 2007).

Distribution data were compiled for twentyseven species of threatened invertebrates, but only sixteen of them were selected, on the basis of at least ten available records of occurrence per species, for predictive modeling (Table 1). The records of species occurrence were imported into the Geographic Information System (GIS) Arcgis 9.1. The geographical distribution given by the available records of threatened marine invertebrates along the Brazilian coast is uneven (Fig. 1). The species not included in the present study due to the lack of data in OBIS were Cerianthomorphe brasiliensis Carlgren, 1931; Eunice sebastiani Nonato, 1965; Gecarcinus lagostoma $\mathrm{H}$. Milne Edwards, 1835; Percnon gibbesii (H. Milne Edwards, 1853); Petaloconchus myrakeenae Absalão \& Rios, 1987; and Willeya loya Petersen, 1965. 
Table 1. Geographic distribution, sample size, and bathymetric range of threatened invertebrate species included in this study. Sources of number of records for each species are provided.

\begin{tabular}{|c|c|c|c|c|c|}
\hline \multirow{2}{*}{ Species } & \multirow{2}{*}{$\begin{array}{l}\text { Geographic range of the southwestern } \\
\text { Atlantic** }\end{array}$} & \multirow{2}{*}{$\begin{array}{l}\text { Number of } \\
\text { records }\end{array}$} & \multicolumn{2}{|c|}{ Bathymetric range* } & \multirow{2}{*}{ Source } \\
\hline & & & $\begin{array}{l}\text { Minimum } \\
\text { depth (m) }\end{array}$ & $\begin{array}{l}\text { Maximum } \\
\text { depth }(\mathrm{m})\end{array}$ & \\
\hline \multicolumn{6}{|l|}{ Cnidaria } \\
\hline $\begin{array}{l}\text { Cerianthus brasiliensis } \\
\text { Mello-Leitão, } 1919\end{array}$ & Brazil (from Ceará to São Paulo State) & 2 & - & - & OBIS \\
\hline $\begin{array}{l}\text { Condylactis gigantea } \\
\text { (Weinland, 1860) }\end{array}$ & $\begin{array}{l}\text { Brazil (Maranhão, Bahia, Espírito Santo and } \\
\text { Rio de Janeiro States) }\end{array}$ & 10 & 0 & 30 & OBIS \\
\hline $\begin{array}{l}\text { Millepora alcicornis } \\
\text { Linnaeus, } 1758\end{array}$ & $\begin{array}{l}\text { Brazil (from Maranhão to Rio de Janeiro } \\
\text { State) }\end{array}$ & 120 & - & - & OBIS \\
\hline $\begin{array}{l}\text { Phyllogorgia dilatata } \\
\text { (Esper, 1806) }\end{array}$ & $\begin{array}{l}\text { Brazil (from Maranhão to Rio de Janeiro } \\
\text { State) }\end{array}$ & 29 & 0 & 28 & OBIS \\
\hline \multicolumn{6}{|l|}{ Polychaeta } \\
\hline $\begin{array}{l}\text { Diopatra cuprea } \\
\text { Bosc, } 1802\end{array}$ & Brazil & 8 & - & - & OBIS \\
\hline $\begin{array}{l}\text { Eurythoe complanata } \\
\text { (Pallas, 1778) }\end{array}$ & Brazil & 10 & 0 & 30 & OBIS \\
\hline \multicolumn{6}{|l|}{ Mollusca } \\
\hline $\begin{array}{l}\text { Natica micra } \\
\text { Haas, } 1953\end{array}$ & Brazil (Rio de Janeiro State) & 3 & - & - & OBIS \\
\hline Crustacea & & & & & \\
\hline $\begin{array}{l}\text { Minyocerus angustus } \\
\text { (Dana, 1852) }\end{array}$ & $\begin{array}{l}\text { Venezuela, Suriname and Brazil (from Para } \\
\text { to Santa Catarina State) }\end{array}$ & 2 & 0 & 59 & OBIS \\
\hline \multicolumn{6}{|l|}{ Echinodermata } \\
\hline $\begin{array}{l}\text { Asterina stellifera } \\
\text { (Möbius, 1859) }\end{array}$ & $\begin{array}{l}\text { Brazil (from Rio de Janeiro to Rio Grande } \\
\text { do Sul State) and Uruguay }\end{array}$ & 18 & 0 & 50 & OBIS \\
\hline $\begin{array}{l}\text { Astropecten braziliensis } \\
\text { Müller \& Troschel, } 1842\end{array}$ & Brazil, Uruguay and Argentina & 14 & 7 & 360 & $\begin{array}{l}\text { OBIS, Leo and Pires-Vanin } \\
\text { (2006) }\end{array}$ \\
\hline $\begin{array}{l}\text { A. cingulatus Sladen, } \\
1889\end{array}$ & Brazil, Uruguay and Argentina & 1 & 0 & 1350 & $\begin{array}{l}\text { OBIS, Leo and Pires-Vanin } \\
\text { (2006) }\end{array}$ \\
\hline A. marginatus Gray, 1840 & Brazil and Uruguay & 190 & 6 & 130 & $\begin{array}{l}\text { OBIS, Costa and Nalesso } \\
\text { (2006) }\end{array}$ \\
\hline $\begin{array}{l}\text { Cassidulus mitis Krau, } \\
1954\end{array}$ & Brazil (Rio de Janeiro State) & 1 & - & - & OBIS \\
\hline $\begin{array}{l}\text { Coscinasterias tenuispina } \\
\text { Lamarck, } 1816\end{array}$ & Brazil (from Bahia to São Paulo State) & 11 & 0 & 165 & OBIS \\
\hline $\begin{array}{l}\text { Echinaster (Othilia) } \\
\text { brasiliensis } \\
\text { Müller \& Troschel, } 1842\end{array}$ & Brazil, Uruguay and Argentina & 68 & 0 & 60 & $\begin{array}{l}\text { OBIS, Leo and Pires-Vanin } \\
\text { (2006) }\end{array}$ \\
\hline $\begin{array}{l}\text { E. (Othilia) echinophorus } \\
\text { Lamarck, } 1816\end{array}$ & $\begin{array}{l}\text { Guyanas and Brazil (from Amapa to Rio de } \\
\text { Janeiro State) }\end{array}$ & 2 & 0 & 55 & OBIS \\
\hline $\begin{array}{l}\text { E. (Othilia) guyanensis } \\
\text { Clarck, } 1987\end{array}$ & $\begin{array}{c}\text { Guyanas and Brazil (from Amapa to Rio de } \\
\text { Janeiro State) }\end{array}$ & 2 & 13 & 106 & OBIS \\
\hline $\begin{array}{l}\text { Eucidaris tribuloides } \\
\text { Lamarck, } 1816\end{array}$ & Brazil (from Amapá to São Paulo State) & 72 & 0 & 800 & OBIS \\
\hline $\begin{array}{l}\text { Isostichopus badionotus } \\
\text { (Selenka, 1867) }\end{array}$ & $\begin{array}{l}\text { Colombia, Venezuela and Brazil (from Rio } \\
\text { Grande do Norte to Santa Catarina State) }\end{array}$ & 2 & 0 & 65 & OBIS \\
\hline $\begin{array}{l}\text { Linckia guildingi Gray, } \\
1840\end{array}$ & Brazil (from Amapa to São Paulo State) & 37 & 0 & 300 & OBIS \\
\hline $\begin{array}{l}\text { Luidia clathrata (Say, } \\
1825 \text { ) }\end{array}$ & Venezuela, Guyanas and Brazil & 35 & 0 & 130 & $\begin{array}{l}\text { OBIS, Leo and Pires-Vanin } \\
\text { (2006) }\end{array}$ \\
\hline $\begin{array}{l}\text { L. ludwigi scotti Bell, } \\
1917\end{array}$ & From Venezuela to Argentina & 95 & 30 & 130 & $\begin{array}{l}\text { OBIS, Leo and Pires-Vanin } \\
\text { (2006) }\end{array}$ \\
\hline $\begin{array}{l}\text { L. senegalensis (Lamarck, } \\
1816 \text { ) }\end{array}$ & $\begin{array}{l}\text { From Venezuela to Brazil (from Amapá to } \\
\text { Santa Catarina State) }\end{array}$ & 117 & 0 & 64 & OBIS \\
\hline $\begin{array}{l}\text { Narcissia trigonaria } \\
\text { Sladen, } 1889\end{array}$ & Guyana, Brazil and Uruguay & 6 & 37 & 91 & OBIS \\
\hline $\begin{array}{l}\text { Oreaster reticulatus } \\
\text { (Linnaeus, 1758) }\end{array}$ & Brazil (from Amapá to Santa Catarina State) & 48 & 0 & 70 & OBIS \\
\hline $\begin{array}{l}\text { Paracentrotus gaimardi } \\
\text { (Blainville, 1825) }\end{array}$ & $\begin{array}{l}\text { Brazil (from Rio de Janeiro to Santa Catarina } \\
\text { State) }\end{array}$ & 29 & - & - & OBIS \\
\hline $\begin{array}{l}\text { Synaptula secreta } \\
\text { Ancona Lopez, } 1957\end{array}$ & Brazil (São Paulo State) & 1 & - & - & OBIS \\
\hline
\end{tabular}




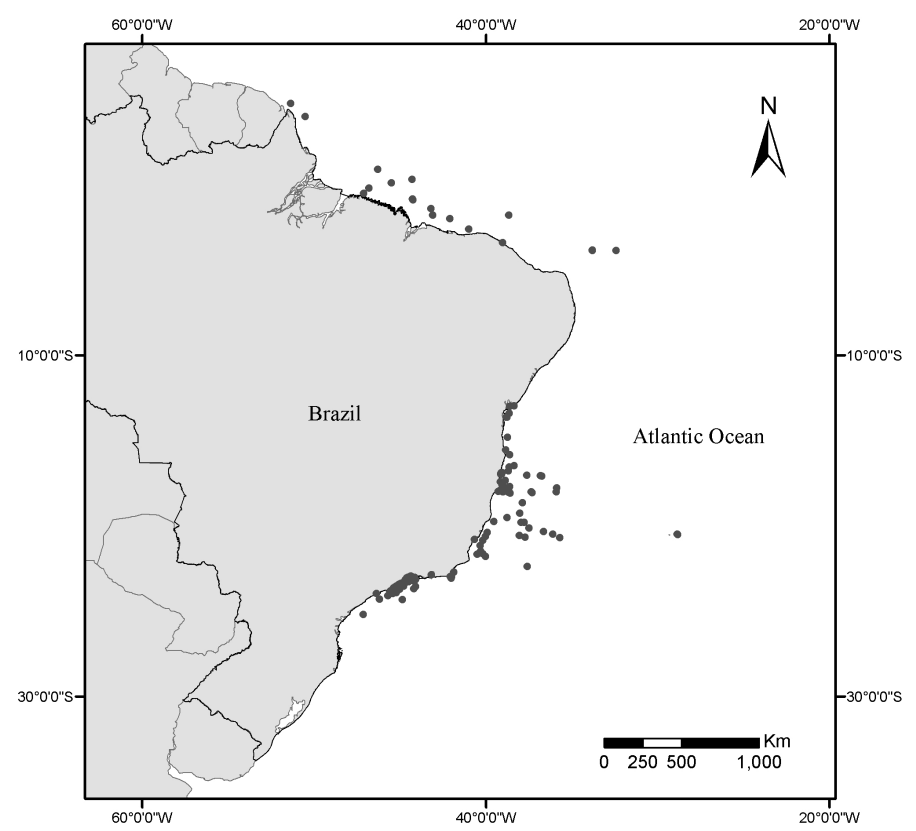

Fig. 1. Occurrence records for threatened marine invertebrates (circles; 933 records).

\section{Environmental Layers}

Our area of study was the southwestern Atlantic region, along the whole Brazilian coast (from $4^{\circ} 30^{\prime} \mathrm{N}-51^{\circ} 37^{\prime} \mathrm{W}$ to $35^{\circ} 30^{\prime} \mathrm{S}-24^{\circ} 38^{\prime} \mathrm{W}$ ), including the entire oceanic area under national jurisdiction.

The environmental variables fall into three categories: temperature, salinity and bathymetry and their derivatives. Other variables, such as type of substrate (i.e., rock, sand, mud), could be chosen in the light of their biological relevance for invertebrate species, but no precise data on them are available for the Brazilian coast. All variables are recorded at a pixel size of $2000 \mathrm{~m}$ by $2000 \mathrm{~m}$. This resulted in a grid comprising 2194 rows and 2656 columns. ArcGIS 9.1 was used for the analyses and processing of all rasters.

Temperature and salinity mean subsurface (for both) were derived from data provided by the National Oceanographic Database (BNDO) of the Hydrography and Navigation Head (DHN) of the Brazilian Navy. The raster datasets were produced using kriging interpolation, based on readings taken at oceanographic stations throughout the southwestern Atlantic between 1994 and 2000. Although measurements taken near the surface may not represent environmental conditions in the benthic zone, they may be used with reasonable caution, especially for shallow-water species (TITTENSOR et al., 2009; VERBRUGGEN et al., 2009). Bathymetry was derived from data made available by the Database of Exploration and Production of the National Agency for Petroleum, Natural Gas and Biofuels. The raster dataset was produced using topo to raster interpolation. Seafloor slope was derived from the same bathymetry model. Rugosity and benthic zone features were produced using the Benthic Terrain Modeler (BTM) tool with bathymetry data sets to examine the deepwater benthic environment. Benthic zone features (flats, depressions, crests and slopes) were created by means of a Bathymetric Position Index (BPI) that utilizes a focal or neighborhood function.

\section{Maximum Entropy Modeling}

Maxent (Maximum entropy modeling) is a general-purpose machine learning method with a simple and precise mathematical formulation, having various aspects well suited for species distribution modeling. Based on environmental conditions, this algorithm infers an approximation of ecological niches of the species from presence-only data (PHILLIPS et al., 2006), having previously been applied to marine organisms (BIGG et al., 2008; TITTENSOR et al., 2009; VERBRUGGEN et al., 2009).

Although a niche-based model describes the suitability of an ecological space, it is typically projected into a geographical space, yielding a 
geographical area for the predicted presence of the species. Areas that satisfy the conditions of a species' fundamental niche represent its potential distribution, whereas the geographical areas it actually inhabits constitute its realized distribution. The realized niche may be smaller than the fundamental niche (with respect to the environmental variables being modeled), in which case the predicted distribution will be smaller than the full potential distribution. However, to the extent that the model accurately portrays the species' fundamental niche, the projection of the model into geographical space will represent the species' potential distribution. Thus, the Maxent modeling approach can be used in its present form for many applications with presence-only datasets (PHILLIPS et al., 2006).

\section{Model Processing and Interpretation}

We used the Maxent software version 3.3.1 (http://www.cs.princeton.edu/ schapire/maxent) to fit the Maxent model, using default model parameters (a convergence threshold of $10^{-5}$, a maximum iteration value of 1000 and automatic regularization with a value $10^{-4}$ ); these default settings have been shown to achieve good performance (PHILLIPS; DUDÍK, 2008). The model output consists of a spatially explicit probability surface that represents an ecological niche (habitat suitability) translated from macroecological space into geographical space (VERBRUGGEN et al., 2009).

For evaluating the performance of our model, we used a cross-validation procedure. For each species, we made 10 random partitions of the occurrence points. Each partition was created by randomly selecting $70 \%$ of the occurrence points as training data and $30 \%$ of the occurrence points as testing data (PHILLIPS et al., 2006). The algorithm was run with all environmental variables (temperature, salinity, bathymetry, slope, benthic zones and rugosity). A jackknife procedure was used to examine the importance of each variable by comparing the model without that variable against that with it. We used a threshold-independent measure, the AUC (area under the curve), to assess our model. AUC is calculated by summing up the area under a receiver operating characteristic (ROC) curve, which is a plot of sensitivity (also known as the true positive rate and representing absence of omission error) against 1 specificity (also known as the false positive rate and representing commission error) for all possible thresholds (PHILLIPS et al., 2006). The value of an AUC index varies between 0 (performance worse than random) and 1 (perfect discrimination), with 0.5 being indistinguishable from random.

To estimate the overlap with the Brazilian MPAs, we first created a filter in the map presented as the full-rank habitat suitability (that varies between 0 - unsuitable - and 1 - highest suitability). Therefore, a fixed threshold of 0.5 was used to convert all the predicted suitable habitats into a map of an only high suitability class. Although subjective, we considered that this threshold was conservative, adequate for the case of threatened species, but that the results had to be interpreted with caution, due to the other environmental variables that had been omitted. Thus we superimposed the geographical extent of the highly suitable areas on the digital map of the Brazilian governmental system of MPAs. Digital maps of the MPAs were compiled from the IBAMA data set (available in http://www.ibama.gov.br/zoneamentoambiental/ucs/), with the use of the ArcGIS 9.1. Currently, MPAs cover an area of approximately 10 $300 \mathrm{~km}^{2}$. This dataset, continuously updated, contains MPAs at the three administrative levels - federal, state and county. In this estimate, we separated the MPAs into two categories with different levels of protection: strict protection and sustainable use.

\section{RESUlTS}

Algorithms consistently produced predictions that were better than random (Table 2). For all partitions of the occurrence data, the AUC values were greater than 0.5 , i.e. models ran better than random. The jackknifing of variables suggested that bathymetry was the most influential environmental variable in determining habitat suitability, though temperature and salinity were also important for some species (Fig. 2).

Predicted suitable habitats for the maximum entropy model are depicted in Figure 3. Highly suitable habitats for threatened marine invertebrates were predicted to occur especially along the Brazilian coast at lesser depths ( $<200$ meters $)$. In general, habitat suitability for all species followed the configuration of the continental shelf, showing that these species are typically neritic forms. Mostly offshore, the algorithm indicated suitable conditions for some species on the Abrolhos Bank and the range of submarine banks Vitória-Trindade (e.g. $C$. tenuispina, M. alcicornis and E. tribuloides). The role of the submarine banks close to Rocas Atoll and Fernando de Noronha Island, and Rio Grande Rise, providing highly suitable areas, can also be observed (e.g. for $E$. complanata, $E$. tribuloides and $L$. guildingi). Other species, such as A. marginatus, E. companata and E. (Othilia) brasiliensis, showed low habitat suitability on the north coast close to the Amazon River. With few exceptions (e.g. Asterina stellifera, Coscinasterias tenuispina, Luidia senegalensis and Paracentrotus gaimardi), the majority of the species occurred in accordance with the pattern of geographical distribution shown in Table 1. These four species had their geographical distributions or bathymetric ranges enlarged. 
Table 2. Mean $( \pm$ SD) of AUC (area under the curve) values for each species $(\mathrm{n}=10)$. Models were calibrated using training data ( $70 \%$ of occurrence points, randomly selected), and AUC values were calculated from test data $(30 \%$ of occurrence data).

\begin{tabular}{lc}
\hline \hline \multicolumn{1}{c}{ Species } & AUC (mean \pm SD) \\
\hline Condylactis gigantea & $1.000 \pm 0.000$ \\
Millepora alcicornis & $0.983 \pm 0.003$ \\
Phyllogorgia dilatata & $0.997 \pm 0.001$ \\
Eurythoe complanata & $0.987 \pm 0.006$ \\
Asterina stellifera & $0.999 \pm 0.001$ \\
Astropecten braziliensis & $0.993 \pm 0.002$ \\
A. marginatus & $1.000 \pm 0.000$ \\
Coscinasterias tenuispina & $0.990 \pm 0.006$ \\
Echinaster (Othilia) brasiliensis & $0.998 \pm 0.001$ \\
Eucidaris tribuloides & $0.987 \pm 0.004$ \\
Linckia guildingi & $0.987 \pm 0.006$ \\
Luidia clathrata & $0.995 \pm 0.003$ \\
L. ludwigi scotti & $0.997 \pm 0.003$ \\
L. senegalensis & $0.998 \pm 0.001$ \\
Oreaster reticulatus & $0.969 \pm 0.014$ \\
Paracentrotus gaimardi & $0.999 \pm 0.001$ \\
\hline
\end{tabular}

The distribution of highly suitable areas for threatened marine invertebrate species showed little overlapping with the government's protected areas (Table 3). Overall, our results showed that species associated with soft-bottom substrata presented less overlapping than did species typical of reef habitats. This was evident for Condylactis gigantea, Phillogorgia dilatata and Millepora alcicornis that had $30.01 \%, 15.36 \%$ and $9.24 \%$, respectively, of high suitability habitats covered by Brazilian MPAs. In general, restricted-range species also presented proportionately more highly suitable areas which overlapped the MPAs than did those species distributed throughout the Brazilian coast, such as Condylactis gigantea, with distribution almost exclusively restricted to the Abrolhos Bank, and Paracentrotus gaimardi, with distribution restricted to the southeastern coast. For all species, the coverage provided by MPAs of strict conservation (more adequate in the case of threatened species) was extremely small.

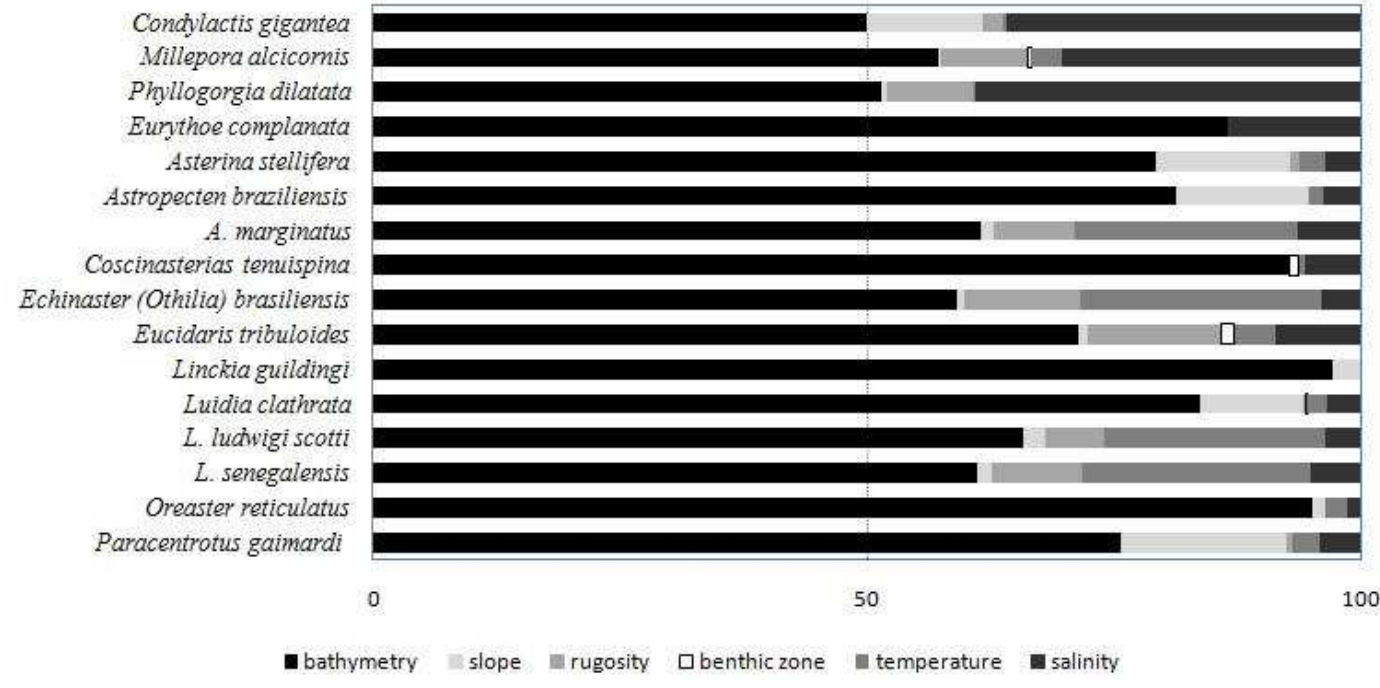

Fig. 2. Selected environmental variables and their percent contribution in Maxent model for threatened marine invertebrate species in Brazilian coast. 


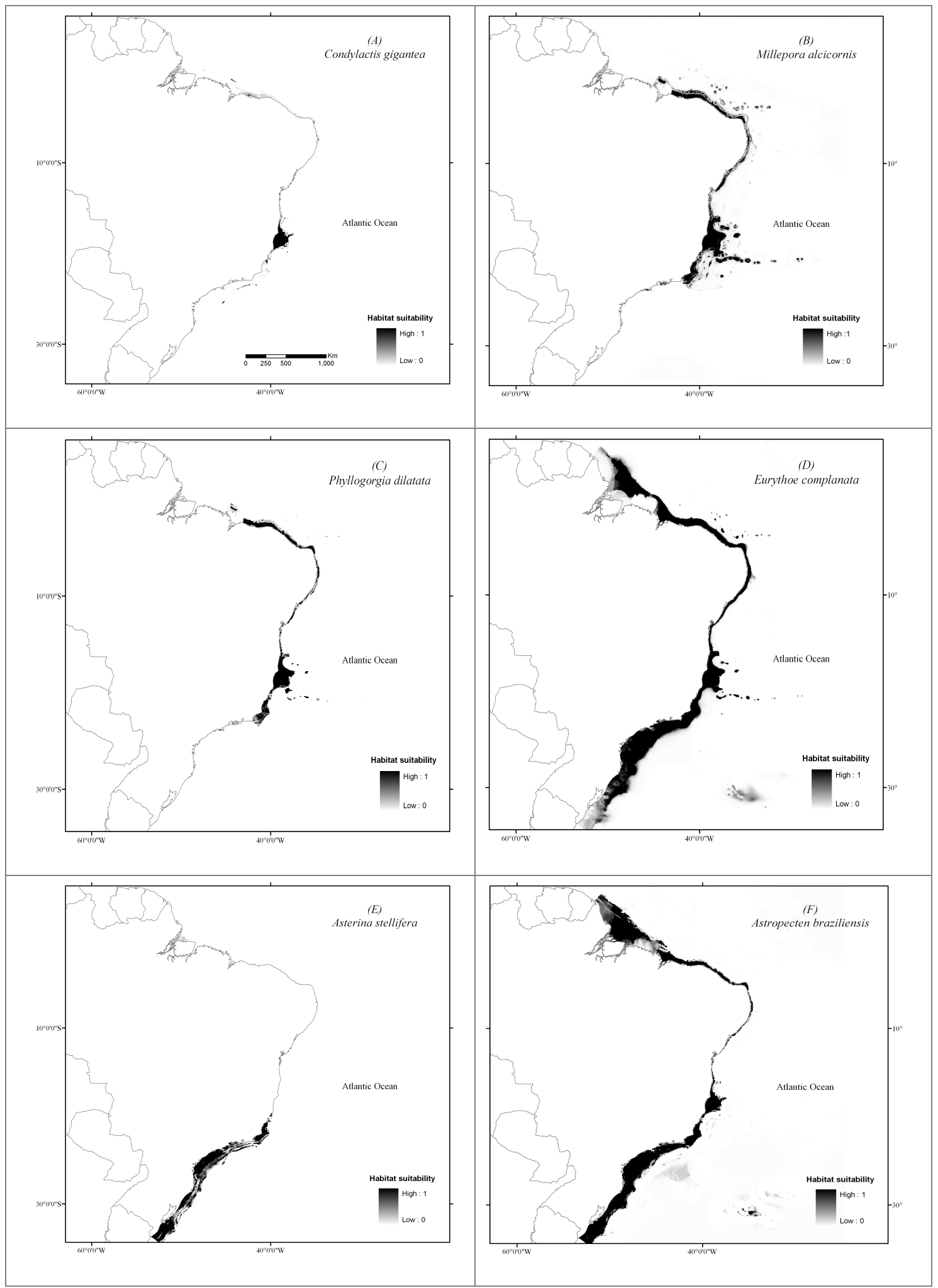

Fig. 3. Predicted potential suitable habitats for threatened marine invertebrate species along the Brazilian coast, using a Maximum Entropy (Maxent) model. Higher values indicate more suitable habitat (cont.). 


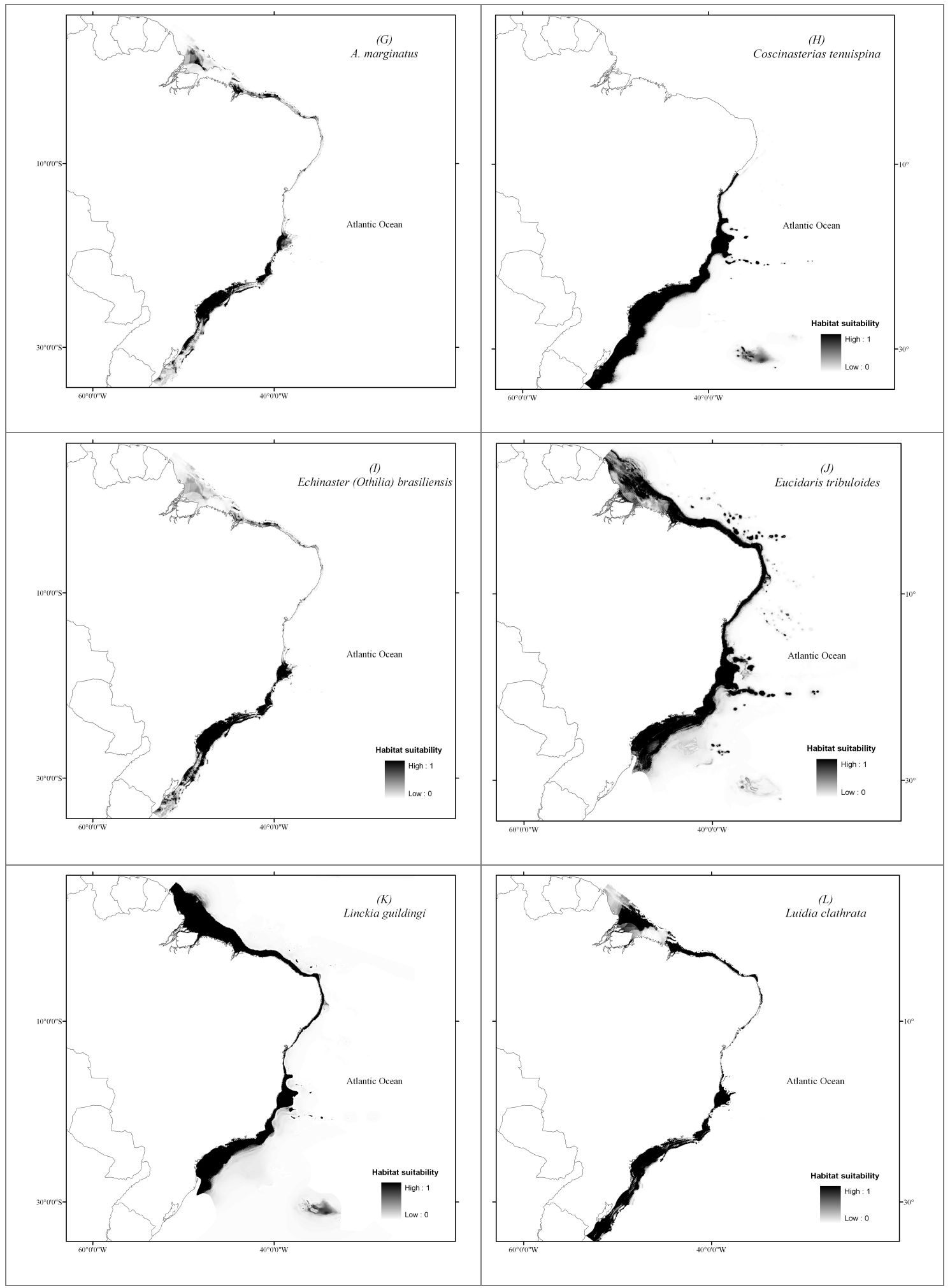

Fig. 3. Predicted potential suitable habitats for threatened marine invertebrate species along the Brazilian coast, using a Maximum Entropy (Maxent) model. Higher values indicate more suitable habitat (cont.). 


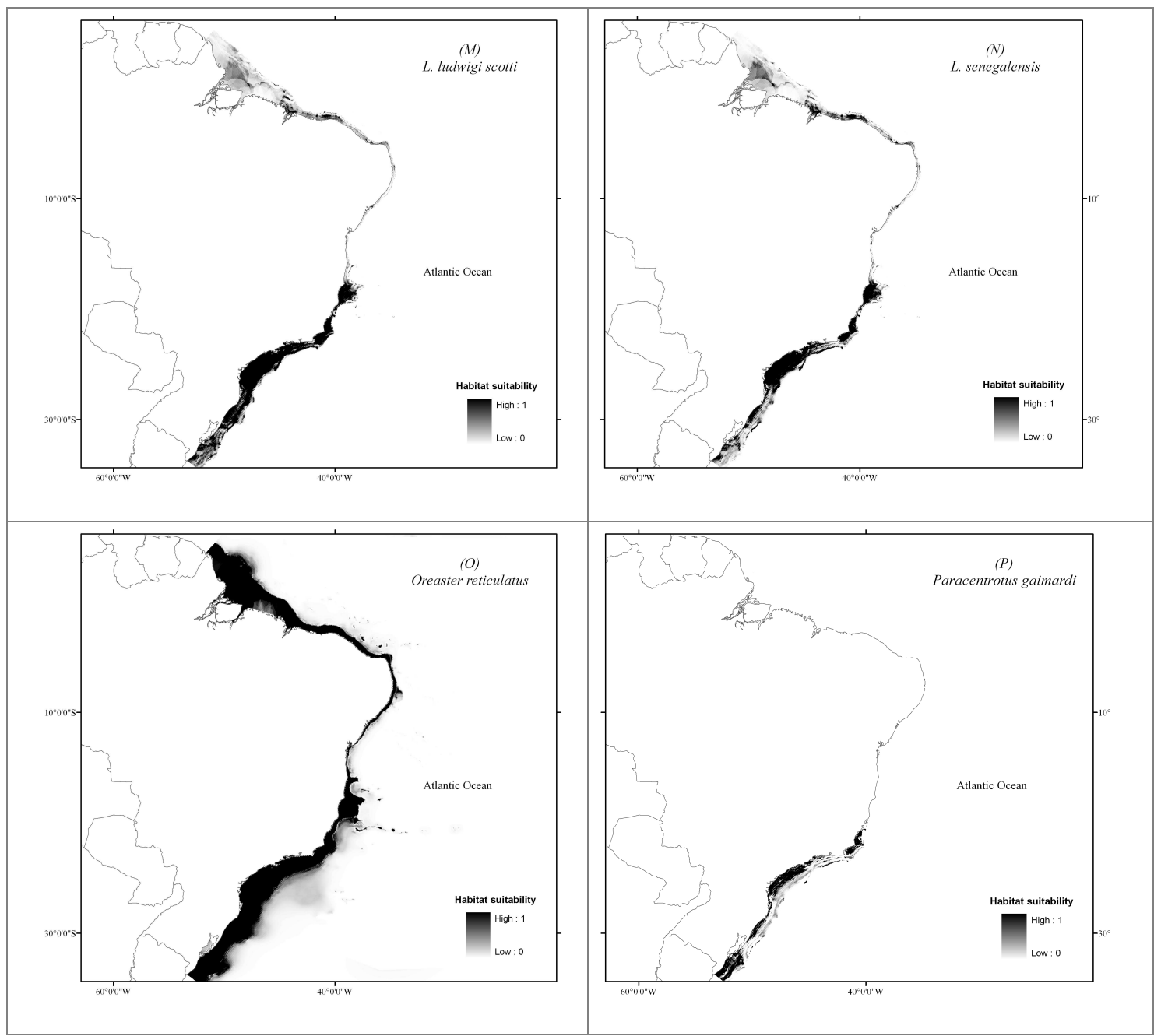

Fig. 3: Predicted potential suitable habitats for threatened marine invertebrate species along the Brazilian coast, using a Maximum Entropy (Maxent) model. Higher values indicate more suitable habitat.

Table 3. Estimated percentage of the highly suitable areas for threatened marine invertebrate species overlapped with Brazilian MPAs.

\begin{tabular}{lccc}
\hline \hline \multicolumn{1}{c}{ Species } & Sustainable use (\%) & Strict conservation $(\%)$ & Total $(\%)$ \\
\hline Condylactis gigantea & 23.70 & 6.31 & 30.01 \\
Millepora alcicornis & 7.83 & 1.41 & 9.24 \\
Phyllogorgia dilatata & 12.20 & 3.16 & 15.36 \\
Eurythoe complanata & 4.90 & 0.58 & 5.48 \\
Asterina stellifera & 3.56 & 0.73 & 4.29 \\
Astropecten braziliensis & 1.77 & 0.52 & 2.29 \\
A. marginatus & 0.13 & 0.37 & 0.50 \\
Coscinasterias tenuispina & 5.01 & 0.47 & 5.48 \\
Echinaster (Othilia) brasiliensis & 0.00 & 0.24 & 0.24 \\
Eucidaris tribuloides & 3.38 & 0.55 & 3.93 \\
Linckia guildingi & 2.63 & 0.58 & 3.22 \\
Luidia clathrata & 5.34 & 1.93 & 7.27 \\
L. ludwigi scotti & 0.02 & 0.31 & 0.33 \\
L. senegalensis & 0.04 & 0.38 & 0.42 \\
Oreaster reticulatus & 2.53 & 0.32 & 2.85 \\
Paracentrotus gaimardi & 10.91 & 3.38 & 14.29 \\
\hline
\end{tabular}




\section{Discussion}

The algorithm produced reasonable predictions of the species' potential distributions (areas of suitable environmental conditions). The models perform digital compilations of the species range designed for use in conservation biology and macro-ecological studies (PHILLIPS et al., 2006). Most strikingly, the models correctly indicated the suitable habitats for most of the species, as may be observed by comparing Table 1 with Figure 3, showing that the patterns predicted by the model are largely consistent with current knowledge of the species. Unsurprisingly, most of the species had a larger range size than expected for tropical benthic taxa. Macpherson (2003) corroborated this statement by demonstrating that the ranges for the benthic species inhabiting the tropical provinces of the western Atlantic are comparatively larger than those for species living at higher latitudes. Moreover, it is important to emphasize that species with enlarged geographical distributions or extended bathymetric ranges need to be validated by field surveys or the judgment of specialists.

Furthermore, the potential habitat distribution map has been used to discover new populations and identify top-priority survey sites (ANDERSON; MARTÍNEZ-MEYER, 2004). Thus, our models may provide predictions of suitable regions in areas not yet well sampled, mainly in the case of the benthic marine organisms that are among the least known taxonomic groups on the northern and northeastern Brazilian coast, due both to inconspicuousness and the absence of population studies (Amaral; Jablonski, 2005).

We have shown that the habitat distribution patterns for threatened marine invertebrate species can be modeled on the basis of a small number of occurrence records and environmental variables using Maxent, even though distribution data on threatened species are often sparse (Engler et al., 2004) and clustered, making commonly used habitat modeling approaches difficult.

The habitat suitability mapping can estimate the extent of occurrence (EOO) of the species, as defined by IUCN (2001). This parameter measures a particular taxon's geographical distribution - which may contain unsuitable or unoccupied habitats, i.e. discontinuities or disjunctions within the overall distributions of taxa. The habitat suitability map of the present study should, therefore, be interpreted with caution because it does not represent a detailed map of actually occupied habitats (i.e. areas of occupancy). This fact is particularly true for species with clumped distributions or with irregularly shape ranges, such as those associated with hard-bottom substrata [e.g. $C$. tenuispina and E. (Othilia) brasiliensis]. Moreover, the original resolution of the climatic and bathymetric data (and the latter's derivatives) is somewhat too coarse adequately to represent patches of the hardbottom substrata.

The role played by the submarine banks close to Rocas Atoll and Fernando de Noronha Island as well as that of the Vitória-Trindade submarine Ridge, which provide conditions suitable for the establishment of populations of echinoderm and cnidarian assemblages, has already been demonstrated for other taxonomic groups (GASPARINI; FLOETER, 2001; JOYEUX et al., 2001; NEUMANNLEITÃO et al., 2008). These environments present relatively shallower waters, with summits coming close to the surface $(10-100 \mathrm{~m})$, and greater trophic complexity, influenced by topographic upwelling (GASPARINI; FLOETER, 2001; STRAMMA et al., 1990), than the surrounding regions. In contrast, the region near the mouth of the Amazon River has an enormous terrigenous input from the freshwater flow acting to separate the marine assemblage fauna (AMARAL; JABLONSKI, 2005; JOYEUX et al. 2001). This probably accounts for the low habitat suitability in shallow waters for some species.

The spatial distribution of marine organisms can be explained by a variety of factors from small to larger-scale. Entrambasaguas et al. (2008) showed that echinoderm assemblages are patchy on spatial scales from hundreds of meters to hundreds of kilometers, but that variability seems to be greater on the finer spatial scale. Those authors suggest that small scale patchiness is to be associated with variations in habitat structure (spatial heterogeneity and complexity) and both are more closely correlated with species belonging to the Asteroidea class. Thus, to improve on the mapping of the current study, habitat suitability modeling should include other information on seafloor characteristics such as rocky substrata, coral and algal covers, numbers of different sized boulders, etc.

Analysis of the environmental variables showed that the influence of bathymetry on the distribution of species was larger than that of climatic factors (temperature and salinity). Water depth is either directly or indirectly related to several variables such as temperature, pressure, light availability, presence and abundance of predator or prey species and food supply, and therefore exerts a first order control over the occurrence of species in the oceans. However, some authors have discussed whether water depth is in fact the most important factor or whether it is an indirect surrogate for the distribution of benthic species (ENTRAMBASAGUAS et al., 2008; HARRIS; WHITEWAY, 2009). Furthermore, there was a strong correlation between many of the environmental variables used in the analyses, and although the model is robust in this regard, the 
jackknife results from the Maxent may only be taken as a guide.

Our results demonstrate that the few suitable areas for threatened species overlap Brazilian MPAs. The higher overlap with Brazilian MPAs found for Condylactis gigantea may be explained as due to this species' almost total restriction to the Abrolhos Bank, which contains greater coastal extensions within the MPAs (e.g., the Extractive Reserve of Corumbau and the Environmental Protection Area of Ponta da Baleia). On the other hand, it is clear that the species associated with soft-bottom substrata (e.g., species of the genus Astropecten and Luidia) had extremely little overlapping with MPAs and, according to MMA (2008), their populations are more vulnerable because a large number of individuals are caught as bycatch in otter trawl fishing.

The result of this study illustrates how the definition of the locations of MPAs is pertinent within the field of marine planning. In general, MPAs have been sited at intrinsically ecologically rich places based more on opportunistic human factors than on relevant ecological and/or socioeconomic features (OJEDA-MARTÍNEZ et al., 2009). Edgard et al. (2008) suggest the incorporation of the key biodiversity area (KBA) approach into marine conservation planning, in the development of MPA networks, using the principles of irreplaceability and vulnerability (sites are those holding one or more threatened species) in the definition of the location of areas. The identification of KBAs on the basis of the species' potential distribution, as well as on the selection of areas where, according to field surveys, the populations are more abundant, are both of fundamental importance for the proposal of new protected areas.

This study has shown how the definition of habitat suitability for threatened marine invertebrates can be accomplished using GIS applications and modeling tools. Research should be targeted to determining how adequate the network of the Brazilian MPAs is, and to ensuring the long-term persistence of biodiversity in the face of increasing human pressure. Similarly, the establishment of a systematic process for the assessment of the truly representative character of the protected area network is essential to guide its strategic strengthening and expansion. We expect that these techniques of spatial analysis will be increasingly used in the continuous assessment of the conservation status of species threatened with extinction, thus providing support for managers responsible for MPA design and creating greater confidence in decision-makers regarding their definition of strategies for conservation purposes. Future efforts should focus on adding new data layers to the environmental variables, on obtaining higherresolution environmental data and on the study of potential priority sites for the conservation of threatened marine invertebrates.

\section{ACKNOWLEDGEMENTS}

We would like to thank the Brazilian Navy (Marinha do Brasil) and the "Agência Nacional do Petróleo, Gás Natural e Biocombustíveis" for making the data essential for this study available to us. We would also thank Fabio Carocci (Fisheries and Aquaculture Department, FAO) and Marinez Siqueira (Instituto de Pesquisa Jardim Botânico) for their assistance in the use of spatial analysis and modeling tools.

\section{REFERENCES}

AMARAL, A. C. Z.; JABLONSKI, S. Conservation of marine and coastal biodiversity in Brazil. Conserv. Biol.,, v. 19, n. 3, p. 625-631, 2005.

ANDERSON, R. P.; MARTÍNEZ-MEYER, E. Modeling species' geographic distributions for preliminary conservation assessments: an implementation with the spiny pocket mice (Heteromys) of Ecuador. Biol. Conserv., v. 116, p. 167- 179, 2004

BERTZKY, M.; STOLL-KLEEMANN, S. Multi-level discrepancies with sharing data on protected areas: What we have and what we need for the global village. J. environ. Mgmt, v. 90, p. 8-24, 2009.

BEST, B. D.; HALPIN, P. N.; FUJIOKA, E.; READ, A. J.; QIAN, S. S.; HAZEN, L. J.; SCHICK, R. S. Geospatial web services within a scientific workflow: Predicting marine mammal habitats in a dynamic environment. Ecol.Inform., v. 2, n. 3, p. 210-223, 2007.

BIGG, G. R.; CUNNINGHAM, C. W.; OTTERSEN, G.; POGSON, G. H.; WADLEY, M. R.; WILLIAMSON, P. Ice-age survival of Atlantic cod: agreement between palaeoecology models and genetics. Proc. biol. sci. / R. Soc., v. 275, p. 163-173, 2008.

BRUNER, A. G.; GULLISON, R. E.; RICE, R. E; FONSECA, G. A. B. Effectiveness of parks in protecting tropical biodiversity. Science, v. 291, p. 125-128, 2001.

COSTA, K. G.; NALESSO, R. C. Effect of mussel farming on macrobenthic community structure in Southeastern Brazil. Aquacult.int., v. 258, p. 656-663, 2006.

EDGAR, G. J.; LANGHAMMER, P. F.; ALLEN, G.; BROOKS, T. M.; BRODIE, J.; CROSSE, W.; DE SILVA, N.; FISHPOOL, L. D. C.; FOSTER, M. N.; KNOX, D. H.; MCCOSKER, J. E.; MCMANUS, R.; MILLAR, A. J. K.; MUGO, R. Key biodiversity areas as globally significant target sites for the conservation of marine biological diversity. . Aquat. Conserv., mar. freshw. Ecosyst., v. 18, p. 969-983, 2008.

ENGLER, R.; GUISAN, A.; RECHSTEINER, L. An improved approach for predicting the distribution of rare and endangered species from occurrence and pseudoabsence data. J. appl. Ecol., v. 41, p. 263-274, 2004.

ENTRAMBASAGUAS, L.; PÉREZ-RUZAFA, A.; GARCÍA-CHARTON, J. A.; STOBART, B.; BACALLADO, J. J. Abundance, spatial distribution and habitat relationships of echinoderms in the Cabo Verde Archipelago (eastern Atlantic). Mar. Freshwat. Res., v. 59, p. $477-488,2008$ 
FABRI, M. C.; GALÉRON, J.; LAROUR, M.; MAUDIRE, G. Combining the Biocean database for deep-sea benthic data with the online Ocean Biogeographic Information System. Mar. Ecol. Progr. Ser., v. 316, p.215-224, 2006

FLEISCHER, D.; SCHABER, M.; PIEPENBURG, D. Atlantic snake pipefish (Entelurus aequoreus) extends its northward distribution range to Svalbard (Arctic Ocean). Polar Biol., v. 30, n. 10, p. 1359-1362, 2007.

GASPARINI, J. L.; FLOETER, S. R. The shore fishes of Trindade Island, western South Atlantic. J. nat. Hist., v. 35, p. 1639-1659, 2001.

GASTON, K. J. Species richness: measure and measurement. In: GASTON, K. J. (Ed.). Biodiversity: a biology of numbers and difference. Oxford: Blackwell Science, 1996. p. 77-113.

HALPERN, B. S.; WALBRIDGE, S.; SELKOE, K. A.; KAPPEL, C. V.; MICHELI, F.; D'AGROSA, C.; BRUNO, J. F.; CASEY, K.S.; EBERT, C.; FOX, H. E.; FUJITA, R.; HEINEMANN, D.; LENIHAN, H. S.; MADIN, E. M. P.; PERRY, M. T.; SELIG, E. R; SPALDING, M.; STENECK, R.; WATSON, R. A global Map of human impact on marine ecosystems. Science, v. 319, p. 948-952, 2008.

HARRIS, P. T.; WHITEWAY, T. High seas marine protected areas: Benthic environmental conservation priorities from a GIS analysis of global ocean biophysical data. Ocean coast. Mngmt, v. 52, n. 1, p. 22-38, 2009.

IUCN. IUCN Red List Categories and Criteria: version 3.1. Gland and Cambridge: IUCN Species Survival Commission, 2001. 32 p.

JOYEUX, J. C.; FLOETER, S. R.; FERREIRA, C. E. L.; GASPARINI, J. L. Biogeography of tropical reef fishes: the South Atlantic puzzle. J. Biogeogr., v. 28, p. 831841,2001

LANGHAMMER, P. F.; BAKARR, M. I.; BENNUN, L. A. BROOKS, T. M.; CLAY, R. P.; DARWALL, W.; DE SILVA, N.; EDGAR, G. J.; EKEN, G.; FISHPOOL, L. D. C.; FONSECA, G. A. B. D.; FOSTER, M. N.; KNOX, D. H.; MATIKU, P.; RADFORD, E. A.; RODRIGUES, A. S. L; SALAMAN, P.; SECHREST, W.; TORDOFF, A. W. Identification and gap analysis of key biodiversity areas: targets for comprehensive protected area systems. Switzerland, 2007. (IUCN Best Practice Protected Areas Guidelines, $\left.\mathrm{n}^{\circ} 15\right)$.

LEO, F. C.; PIRES-VANIN, A. M. S. Benthic megafauna communities under the influence of the South Atlantic Central Water intrusion onto the Brazilian SE shelf: a comparison between an upwelling and non-upwelling ecosystem. J. mar. Syst., v. 60, p. 268-284, 2006.

MACPHERSON, E. Species range size distributions for some marine taxa in the Atlantic Ocean. Effect of latitude and depth. Biol. J. Linn. Soc. Lond, v. 80, p. 437-455, 2003

MMA - MINISTÉRIO DO MEIO AMBIENTE. Livro vermelho da fauna brasileira ameaçada de extinção. v. 1. Brasília, DF,2008. 511 p.(Biodiversidade, 19.).

MILLENNIUM ECOSYSTEM ASSESSMENT. Ecosystems and human well-being: Synthesis. Washington, DC: Island Press, $2005.160 \mathrm{p}$.
NEUMANN-LEITÃO, S.; SANT'ANNA, E. M. E.; GUSMÃO, L. M. O.; NASCIMENTO-VIEIRA, D. A.; PARANAGUÁ, M. N.; SCHWAMBORN, R. Diversity and distribution of the mesozooplankton in the tropical Southwestern Atlantic. J. Plank. Res., v.30, p. 795-805, 2008.

OJEDA-MARTÍNEZ, C.; CASALDUERO, F.G.; BAYLESEMPERE, J.T.; CEBRIÁN, C.B.; VALLE, C.; SANCHEZ-LIZASO, J.L.; FORCADA, A.; SANCHEZJEREZ, P.; MARTÍN-SOSA, P.; FALCÓN, J.M.; SALAS, F.; GRAZIANO, M.; CHEMELLO, R.; STOBART, B.; CARTAGENA, P.; PÉREZ-RUZAFA, A.; VANDEPERRE, F.; ROCHEL, E.; PLANES, S.; BRITO, A. A conceptual framework for the integral management of marine protected areas. Ocean coast. Mgmt, v. 52, n. 2, p. 89-101, 2009.

PÉREZ-RUZAFA, A.; MARCOS, C.; GARCÍACHARTON, J.A.; SALAS, F. European marine protected areas (MPAs) as tools for fisheries management and conservation. J. Nat. Conserv., v.16, p. 187-192, 2008.

PHILLIPS, S.T; ANDERSON, R.P; SCHAPIRE, R.E. Maximum entropy modeling of species geographic distributions. Ecol. Model., v. 190, p. 231-259, 2006.

PHILLIPS, S.T.; DUDÍK, M. Modeling of species distributions with Maxent: new extensions and a comprehensive evaluation. Ecography, v. 31, p. 161$175,2008$.

ROTENBERRY, J. T.; PRESTON, K. L.; KNICK, S. T. GISbased niche modeling for mapping species' habitat. Ecology, v. 87, n. 6, p. 1458-1464, 2006.

STRAMMA, L.; IKEDA, Y.; PETERSON, R. G. Geostrophic transport in the Brazil Current region north of $20^{\circ}$ S. Deep-Sea Res., v. 37, p. 1875-1886, 1990.

TITTENSOR, D. P.; BACO, A. R.; BREWIN, P. E.; CLARCK, M. R.; CONSALVEY, M.; HALLSPENCER, J.; ROWDEN, A. A.; SCHLACHER, T.; STOCKS. K. I.; ROGERS, A. D. Predicting global habitat suitability for stony corals on seamounts. J. Biogeogr., v. 36, n. 6, p.1111-1128, 2009.

UNEP. Report on the Sixth Meeting of the Conference of the Parties to the Convention on Biological Diversity (UNEP/CBD/COP/6/20/Part2). 2002. Available from: http://www.cbd.int/doc/meetings/cop/cop-

06/official/cop-06-20-part2-en.pdf. Accessed: 12 March, 2009.

VERBRUGGEN, H.; TYBERGHEIN, L.; PAULY, K.; VLAEMINCK, C.; VAN NIEUWENHUYZE, K.; KOOISTRA, W.H.C.F.; LELIAERT, F.; DE CLERCK, O. Macroecology meets macroevolution: evolutionary niche dynamics in the seaweed Halimeda. Global Ecol. Biogeog., v. 18 (3), p.392-404, 2009.

(Manuscript received 04 June 2009; revised 22 June 2010; accepted 26 October 2010) 